\title{
Physical modeling applied in evaluation of the safety and efficiency of vessel mooring plans
}

\section{Aplicação de modelagem física na avaliação da segurança e eficiência de sistemas de amarração de navios}

\author{
Rafael Esferra ${ }^{1}$, José Carlos de Melo Bernardino ${ }^{2}$ and Paolo Alfredini ${ }^{2}$ \\ ${ }^{1}$ Fundação Centro Tecnológico de Hidráulica, São Paulo, SP, Brasil \\ ${ }^{2}$ Universidade de São Paulo, São Paulo, SP, Brasil \\ E-mails: resferra@gmail.com (RE); jcarlosmbernardino@usp.br (JCMB); alfredin@usp.br (PA)
}

Received: December 09, 2017 - Revised: March 20, 2018 - Accepted: May 26, 2018

\begin{abstract}
For cargo handling to be carried out safely and efficiently, port terminals should provide favorable conditions of shelter, thus avoiding excessive movement of moored vessels and mitigating strengths on mooring lines. However, terminals in which the influence of waves, winds or currents provide adverse conditions to keep a vessel moored need to pay attention to the mooring arrangement of the vessels, through studies that guarantee the effectiveness of the system. In this context, small-scale hydraulic physical models are the most accurate tool for simulation of mooring lines plans of vessels, since they can accurately reproduce all the complexity of the hydrodynamics and its interaction with the vessel. This manuscript presents the technique of physical modeling in vessel mooring studies and its application in a case study made for Ponta da Madeira Port Terminal. In a scale model 1:170 was carried out a comparison of two proposed mooring arrangements for the Valemax class bulk carrier, the results of which allowed to define a safe alternative that made the berthing operation feasible during almost $100 \%$ of the time.
\end{abstract}

Keywords: Port engineering; Mooring arrangements for vessels; Scale models.

\section{RESUMO}

Para que a movimentação de carga seja realizada de forma segura e eficiente, os terminais portuários devem proporcionar condições favoráveis de abrigo, evitando assim a movimentação excessiva das embarcações atracadas e mitigando os esforços sobre os cabos de amarração. No entanto, terminais, nos quais a influência de ondas, ventos ou correntes proporcionam condições adversas para manter uma embarcação atracada, precisam dar atenção especial ao sistema de amarração dos navios, por meio de estudos que garantam a eficácia do sistema. Neste âmbito, os modelos físicos hidráulicos em escala reduzida se apresentam como a ferramenta mais precisa para simulação de planos de amarração de navios, pois são capazes de reproduzir fielmente toda a complexidade das ações hidrodinâmicas e sua interação com a embarcação. Este artigo apresenta a técnica da modelagem física em estudos de amarração de navios e sua aplicação em um estudo de caso desenvolvido para o Terminal Portuário Ponta da Madeira, para o qual, em um modelo físico na escala 1:170, foi realizada uma comparação de dois planos de amarração para o navio graneleiro da classe Valemax, cujos resultados permitiram definir uma alternativa segura e que tornou viável a operação do berço de atracação durante 100\% do tempo.

Palavras-chave: Engenharia portuária; Planos de amarração de navios; Modelos físicos reduzidos. 


\section{INTRODUCTION}

In the port operations of cargo handling it is necessary that the layout of the protection and berthing structures provides adequate and safe conditions of shelter in the berth area so that there is no excessive strenghts on mooring lines of vessels, and not even excessive movements of these moored vessels during the loading and unloading procedures. Currently, in order to verify the operation conditions of moored vessels in wharfs or piers, international recommendations such as OCIMF (2013) and PIANC (1995) has guided that the following factors must be considered: winds, currents, waves, passing ships effects, variation of vessel draft and tide.

In addition to the concern with a favorable location for the port and possible improvements of protection structures, the effectiveness of the mooring system must be considered, which generally consists of the vessels own ropes and port infrastructure. However, some quite specific terminals have more unfavorable conditions for cargo handling, with berths partial or no sheltered from the environmental actions, or even in critical conditions related to the passing ships very closely to the berths. In these cases, special attention is required to the mooring arrangement, which needs to be evaluated with the use of more accurate analysis tools, to avoid accidents and damages in the operation of the port terminal. In this context, the scale models are the most recommended tool to evaluate scenarios of critical conditions of the cargo handling, accurately, reproducing all the hydraulic conditions that occurs on the moored vessel.

There are also other approaches to carry out a mooring arrangement analysis such as analytical method and computational modeling. In the analytical method, mathematical equations are used to determine the wind and current strengths acting on the vessel. These equations can be found in OCIMF (2013) and solved manually or with a simple help from an electronic spreadsheet. In this method, the assessment of the mooring system is carried out in a static way, with one vector representing the action of the current and other representing the wind and without considering the movement of the vessel. The wind force vector is applied on the vessel windage area and the current force vector on the underwater area of the vessel. The analysis consists in the balance of forces and moments applied on the vessel by environmental actions with the opposite reactions by the mooring lines and fenders.

In the computational approach, in general, the analysis involves the use of a hydrodynamic model and a mooring dynamics model. The first determines the characteristics of the environmental actions, such as speed and direction of currents, winds and waves. The second model calculates by numerical processing the movement of the vessel and the forces in the mooring lines and fenders using as input parameter the forces on the vessel obtained by the first model. In these models, vessel movement is considered in the time domain, and thus the strengths in the lines can be calculated in this same domain. The representation of environmental actions such as currents, waves and winds, as well as the solution of the differential equations of the fluid / structure interaction are numerically simplified in this type of modeling. Even in the most advanced computational models, the calibration coefficients of the simplified numerical solutions of the differential equations of the motion need to be determined from another source, which is usually the results of tests on scale models or even field data resulting from measurements on real vessels.

On the other hand, the physical models represent the engineering structures in a small scale, with the interaction fluid / structures evaluated directly by the action of the water on the port structures and the hull of the vessel, reproduced in conditions of geometric similarity with respect to the real structures. However, for the correct representation of the phenomena involved, the scale model must respect some physical constraints, which will allow to obtain the mechanical similarity with the prototype (real). For the studies on scale models involving estuarine hydraulic phenomena, Froude's similarity criteria must be respected, as described in Hughes (2005). This criterion establishes the relations of extrapolation for the prototype of the various quantities measured in the physical model.

The definition of the type of modeling for verification, validation or optimization of a project will depend on the characteristics of the region and what one intends to study. For example, in a study case to verify the mooring arrangement of a port terminal in a region with moderate environmental conditions, where the dynamic actions on the vessel can be represented in a simplified way, or in places where the movement of the moored vessel is relatively small and does not produce significant second-order effects on mooring lines, the analytical method or computational models can produce preliminary comparative results for engineering studies. However, if the movement of the vessel is relevant in the propagation of the forces in the lines, or if the region under study is characterized by complex dynamic actions on the vessel, the most appropriate is the application of the physical modeling.

In this paper, the study case is the improvement of the mooring system of the North Berth of Pier IV, at the Ponta da Madeira Port Terminal (TPPM), located in the Bay of São Marcos - MA, where the tide regime is "semidiurnal", with tidal ranges of greater occurrence between 5.0 and $5.5 \mathrm{~m}$, being able to reach up to $6.5 \mathrm{~m}$ in equinoctial spring tides. Due to this periodic sea level variation, the tidal currents near the terminal can reach high speeds, about 7 knots, which makes this Port Terminal unique in the world. In relation to the other environmental conditions, this area is well sheltered from the action of waves, and the winds only have some influence on moored vessels at the beginning of loading (ballasted), but much smaller than the currents. Thus, for practical purposes, the currents can be considered as the only forcing to evaluate in the mooring of vessels in the TPPM.

Furthermore, the field of currents near the mooring berths of the TPPM is extremely complex: besides the effects of the tide variation, the local flow has the formation of large recirculation areas, in addition to intense eddies close to terminal structures. In this environment, berthed vessels, which can reach lengths of more than $360 \mathrm{~m}$, with a capacity to load up to 400 thousand tons of ore, require a reinforced mooring arrangement. To improve the vessels safety, the Terminal operation decided for by complimenting the mooring system of the vessels through more resistant lines coming from the pier.

As described in American Society of Civil Engineers (ASCE, 2014), if the study is for regions where wave and current field actions are complex, it is recommended to use physical modeling to verify and develop the mooring system. 
Therefore, due to the complexity of the study area and the size of the vessels that dock at the TPPM, to guarantee the safety during mooring of moored vessels, mooring plans studies were developed in a physical hydraulic model of scale reduced.

The goal of this article is to present the analysis method for mooring systems using physical modeling, presenting the technique for carrying out the tests and the results from the case study.

\section{MATERIALS AND METHODS}

In physical hydraulic models of estuarine and port regions is possible to simulate different scenarios of environmental conditions (tides, currents and waves), different types of vessels, different loading plans, types of mooring lines, positioning of vessels in berths, among other assessments. In addition to the possibility of verifying the numerous factors surrounding a mooring system, scale models can, unlikely other types of modeling, accurately reproducing the hydrodynamic fields of currents and waves, especially in environments with a greater degree of complexity. Despite the scale effects, which can be conveniently mitigated for the region of interest, small scale physical modeling is still the safest tool for evaluation of mooring systems in coastal and estuarine port environments

Therefore, for the elaboration of this study, the reduced hydraulic physical model of TPPM, constructed in the non-distorted scale of 1: 170, was used in an area of the CTH-USP (Hydraulic Technological Center of the University of São Paulo) with approximately $1,700 \mathrm{~m}^{2}$. The model covers a portion of São Marcus Bay, ranging from the Itaqui Port, located south of TPPM, to the region of the Medo and Sisters Islands, in the north. All the mooring and sheltering structures present in TPPM are represented in the model, as can be observed in Figure 1.

As mentioned earlier, due to TPPM natural shelter from wave action, and the low importance of the winds, the physical model was designed for exclusive representation of the tidal currents of the region, these being the main constraints for berthing. Thus, to ensure the representation of the local flow in the model, it was necessary to respect conditions of hydraulic similarity, which in the case of the free flow are guaranteed by the dimensionless Froude number of model and prototype. The Froude number $(\mathrm{Fr})$, as it is known, can be written as:

$F r=U / \sqrt{g \cdot y}$

Where, $g$ is the gravitational acceleration and $y$ is the mean depth of the free surface flow.

With the Froude number of the flow in the model being equal to that of the prototype, the so-called froudian models guarantee an adequate representation of the relation between the inertial forces and the gravitational forces, which is the most important for the studied problem. However, because of the geometric scale reduction factor $(\lambda)$, it is necessary to ensure that other forces involved in the flow, such as those due to water viscosity or surface tension, and which are not represented in this type of physical model, are negligible in the representation of the studied phenomenon, thus avoiding the so-called scale effects. The effects due to not represent the viscosity of the water in small-scale models, for example, can be ignored whenever the flow in the model is

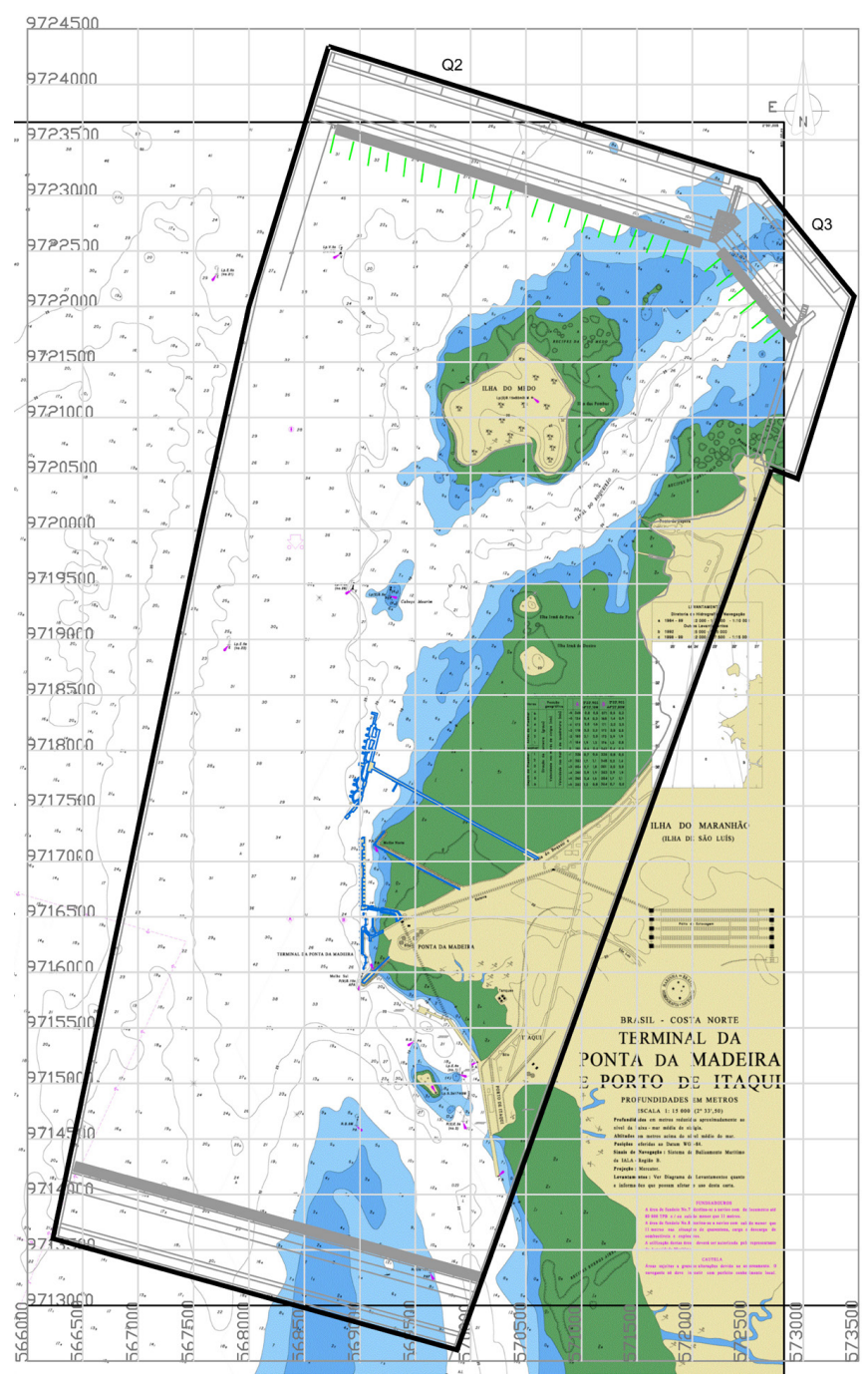

Figure 1. Nautical Chart No 413 form Diretoria de Hidrografia e Navegação da Marinha do Brasil superimposed by the area reproduced by the physical model.

turbulent. This can be achieved by observing a minimum reduction scale for the physical model $(1: \lambda)$ min, which can be obtained by the Zeghzda criterion (NOVAK; CABELKA, 1981). Using the logarithmic expression for the characterization of turbulent flow velocity distribution, the minimum scale of the physical model can be calculated from the expression:

$\frac{1}{\lambda}=\left\{\left(\frac{126}{R e_{p}}\right) \cdot\left(\frac{D_{H}}{\varepsilon}\right)_{p} \cdot\left[-2 \log \left(\frac{\varepsilon}{3,71 \cdot D_{H}}\right)_{p}\right]\right\}^{2 / 3}$

Where:

- Subscript "p": means prototype values;

- Re: Reynolds number $\left(R e=U \cdot D_{H} / v\right)$

- U: mean flow velocity;

- $\mathrm{D}_{\mathrm{H}}$ : hydraulic diameter;

- $\quad$ : water kynematic viscosity $\left(10^{-6} \mathrm{~m}^{2} / \mathrm{s}\right)$; 
- $\varepsilon$ : bottom roughness, which can be estimated by $\varepsilon=(26 . n)^{6}$ (KOBUS, 1981);

- $n$ : Manning number.

Thus, for the mooring area of the TPPM, in which the flow velocities are close to 6 knots (approximately $3 \mathrm{~m} / \mathrm{s}$ ), the mean flow depth is about $25 \mathrm{~m}$ (the hydraulic diameter can be approximated by 4 times this value) and the Manning number is close to 0.035 (value obtained from calibration in a computational model presented later in this paper), the minimum scale calculated by Equation $(2)$ results in: $(1 / \lambda) \approx 1 / 179$. Therefore, the scale adopted for the reduced model of TPPM $(1 / 170)$ has scale effects that can be ignored, in the mooring area, in the flow phenomena with respect to the viscosity. In Alfredini (1988) are presented with more detailed considerations in respect.

In the present study, the scale effects due to the water surface tension, and the viscosity, could be important for the correct characterization of the flow rotationality and, therefore, in the formation of vortices, especially in the lower flow velocities areas. However, to reduce these effects less reduced scales would have to be used, which would compromise the reproduction of the minimum boundary condition necessary for properly represent the flow in the physical model. In the case of TPPM, considering the magnitudes of flow velocities near mooring berths, it is known that although there may be scale effects due to the water surface tension in the reproduction of the flow, these are secondary compared to the dynamic action of the flow on the vessel, which is well characterized in this model. In Alfredini (1988) are presented with more detailed considerations in respect

The equality between the Froude number of model and prototype establishes, by itself, the conditions to extrapolate the small scale measured quantities to the real environment. Since the relation between linear quantities of prototype and model is the geometric scale itself $(\lambda)$, other fundamental quantities can be written in relation to this scale factor:

- Velocity scale: $U_{p} / U_{m}=\lambda^{1 / 2}$

- Volume flow rate scale: $Q_{p} / Q_{m}=\lambda^{5 / 2}$

- Time scale: $t_{p} / t_{m}=\lambda^{1 / 2}$
- Force scale: $F_{p} / F_{m}=\lambda^{3}$

In the above relations, the subscript " $p$ " refers to "prototype" values and the "m" subscript refers to models values.

In addition to the topographic and bathymetric characteristics of the region, the vessels are also reproduced in small scale. For this, based on the arrangement of lines and the general arrangement of the real vessel, the hull model and the mooring elements are made respecting the geometric similarity (Figure 2). Furthermore, the vessel's model is calibrated based in real vessel building data, using mainly the characteristics of center of gravity and rotation radius (FCTH, 2015). The hydrodynamic calibration of the vessel's hull is less important in the mooring assessment tests, but since these reduced vessel models are also used by CTH-USP in other types of simulations, such as maneuver tests, this type of calibration is also made in an appropriate tank, as described in Bernardino (2015). Thus, it is guaranteed that the movements, accelerations and other variables of the phenomenon under study will be represented in conditions of similarity with the prototype.

The calibration process of the currents in the scale model used current speed, direction and water level data collected in georeferenced points during one-year field survey campaign. Twenty-four homologous points were defined in the scale model for the calibration of the velocity and direction of the tidal currents, with the aid of MicroADV (Acoustic Doppler Velocimeter) and depth probes, to verify the water level, applying the methodology presented in Bernardino (2015). The scale model of TPPM (Figure 3 ) is calibrated and validated for the conditions of flood and ebb currents and can represent any tidal range in the from $3.0 \mathrm{~m}$ to $7.0 \mathrm{~m}$, which is enough to represent the local tidal range.

During the studies for vessel moring arrangement assessment and improvement carried at TPPM's PIV North Berth, the scale model tests counted with the measurement of two main parameters: the working strengths in mooring lines and the vessels movements. With this data it is possible to evaluate the effectiveness of the mooring arrangement, according to criteria presented by the international recommendations of OCIMF (2013) and PIANC (1995).

The physical modeling of the mooring system is obtained through rope assemblies connected to coiled springs, as shown in Figure 4. The springs are calibrated on a specific bench to reproduce the real rope linear modulus of elasticity in a reduced

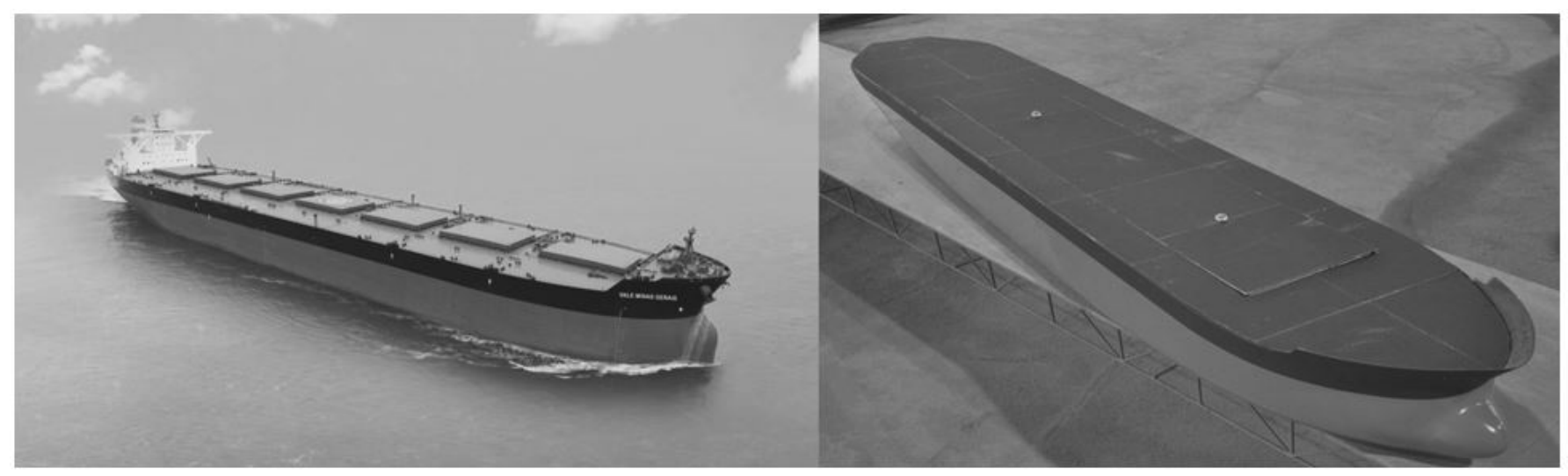

Figure 2. Actual Valemax 400,000 DWT (deadweight tons) vessel (left) and his model in the reduced scale of 1:170 (right). 
scale, respecting the curves of strength $\times$ deformation for each rope to be represented. The determination of the strengths in each rope is made by measuring the elongation of the respective spring during the test and applying the Hooke's Law to establish the relation between the displacement and strength. The sensors that measure the spring displacements in the physical model are called LVDT (Linear Variable Differential Transformer), and the obtained values are recorded every second in a computational database for subsequent strength pattern analysis in the lines throughout the whole test. The positions and elevations of the mooring devices

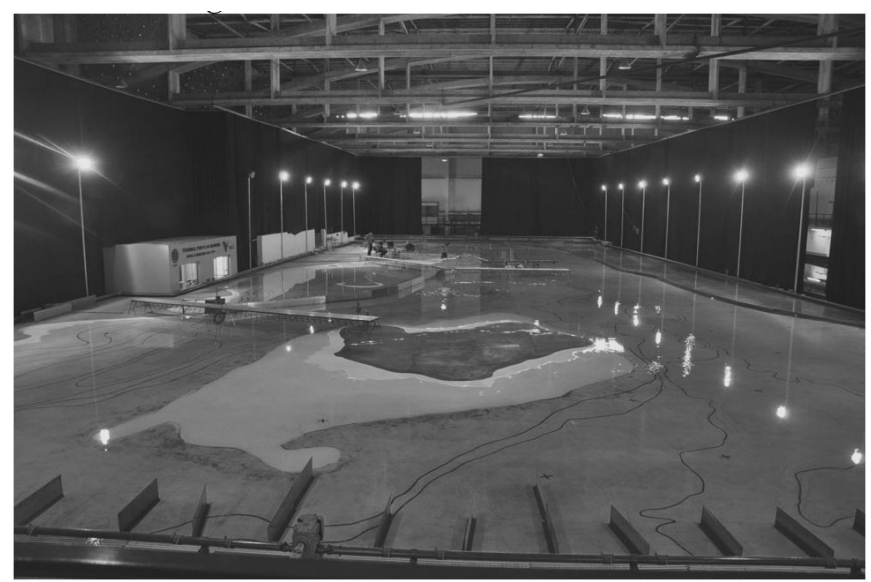

Figure 3. Overview (from real north to south) from the physical scaled model of TPPM (Terminal Portuário Ponta da Madeira) and its adjacent areas (Scale 1:170). Source: CTH-USP collection.

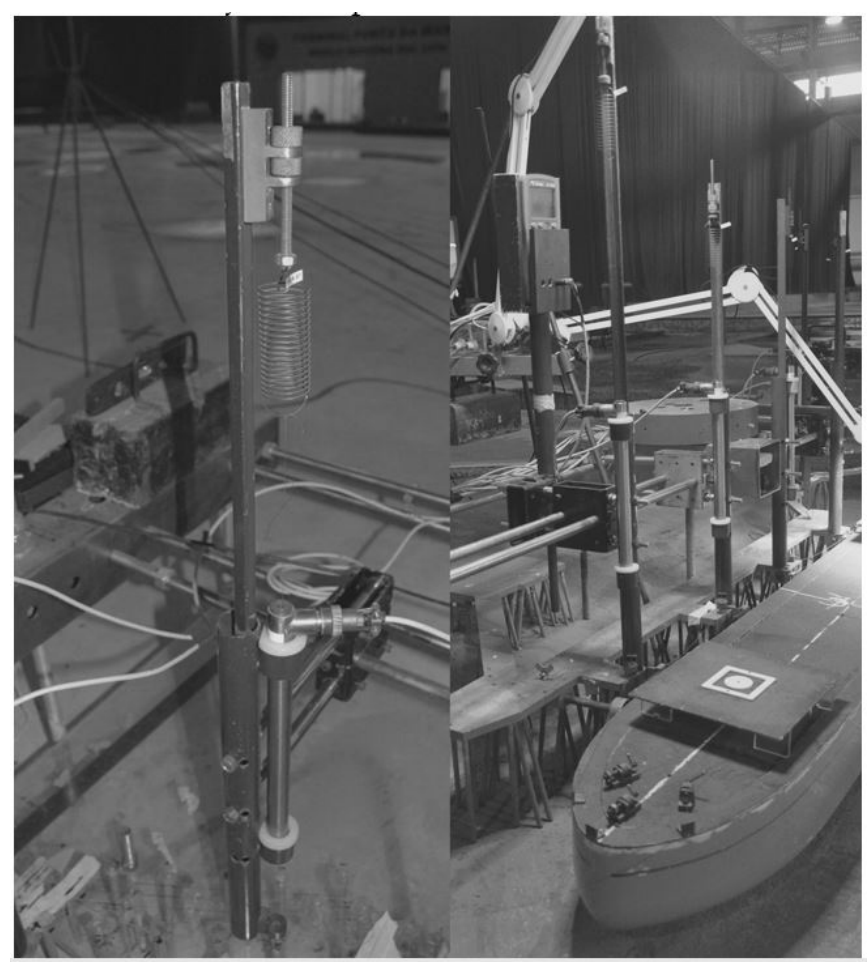

Figure 4. System for the reproduction and measurement of mooring rope strength in the small-scale model, using helical springs with the mooring ropes and the sensor LVDT (Linear Variable Differential Transformer). Source: CTH-USP collection. on the vessel and on the pier are precisely respected, ensuring the correct representation of the angles between the lines and pier and the lines and the vessel observed in the Terminal. Prior to the start of the test itself, with the vessel fixed at the berthing line and centered on the berth, the lines are strenghtened to $10 \%$ of the MBL (Minimum Breaking Load, which is the reference of the minimum nominal breaking load of one rope), like what happens in the mooring of an actual vessel. This prestrenght is measured using the same coil displacement measurement system explained above.

The vessel's movements are registered by a system composed of two cameras equidistant from the vessel's instantaneous center of rotation and two fixed targets on the deck (Figure 5). From the vessel initial position, the system can measure the movements in 3 degrees of freedom (Yaw, Surge and Sway, as shown in Figure 6) during the test, which is sufficient to represent the movements of vessels moored in locations protected from wave actions.

The optimization study for the mooring arrangement used at Pier IV's North Berth was developed considering two distinct scenarios: mooring only with on-board lines and mooring with the help of pier's lines. For this evaluation, the model of the Valemax vessel was used, considering the total load of 400,000 DWT (deadweight tons), with a draft of $23 \mathrm{~m}$, berthed by starboard.

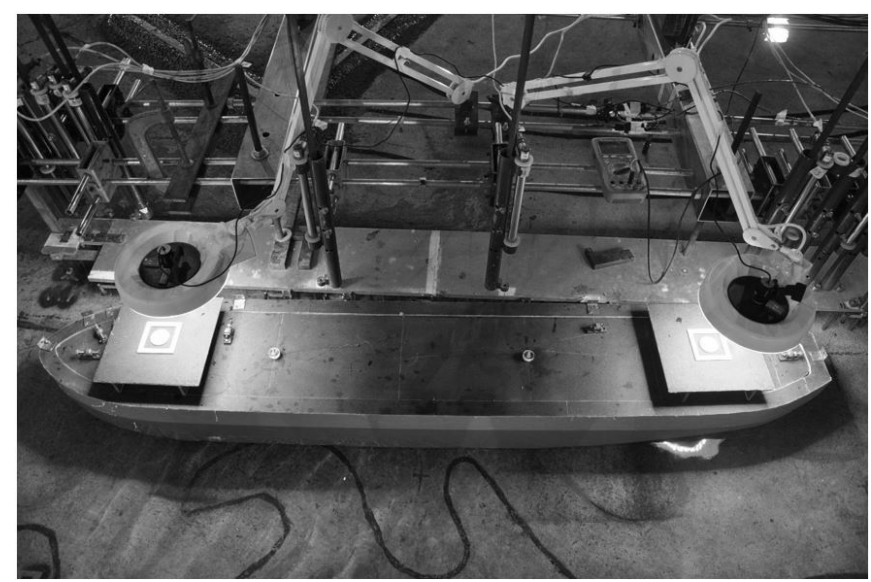

Figure 5. Image Analysis System for vessel movements measurement in small-scale. Source: CTH-USP collection.

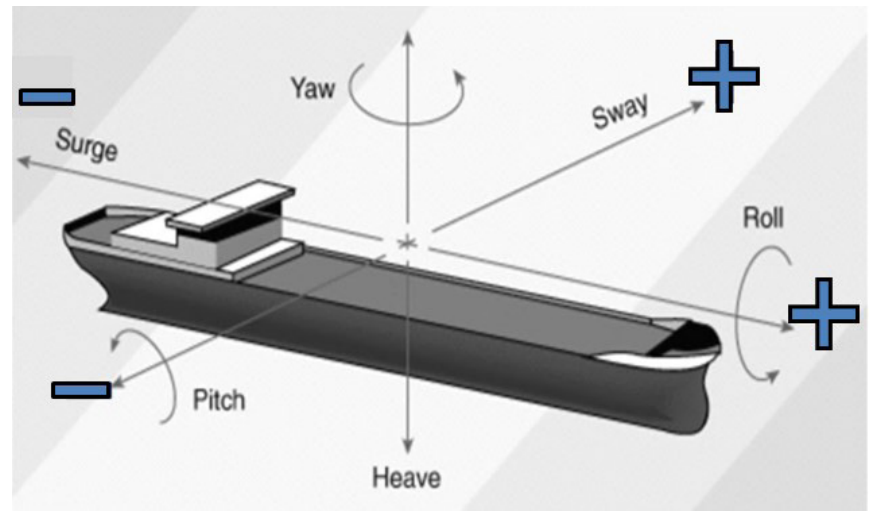

Figure 6. Simplified Scheme showing the types of displacements that a moored vessel can suffer. 
The tests were performed for tidal ranges from $5.5 \mathrm{~m}$ to $6.5 \mathrm{~m}$, the water level and velocity of the model were adjusted to represent the MSL moment, which is the most intensive time in relation to the velocity variation. The tests were carried out for flood and ebb conditions, starting with the tidal range of $5.5 \mathrm{~m}$ to the tidal range when the strength in at least one rope exceeded the limit of $55 \%$ of the MBL, or the movements of the vessel exceeded the maximum horizontal limit recommended in PIANC (1995). For belt loaders, the maximum allowable displacements are:

$$
\begin{aligned}
& \text { Surge }-5.0 \mathrm{~m} \text { (peak to peak) } \\
& \text { Sway }-2.5 \mathrm{~m} \text { (from the berthing line) } \\
& \text { Yaw }-3.0^{\circ} \text { (peak to peak) }
\end{aligned}
$$

The mooring arrangement of the vessels, which are the projects that present the position of the ropes and their characteristics, were elaborated considering ropes working as head, breasting and spring (as represented schematically in Figure 7). In scale models, it is often not possible to represent all ropes individually due to the small scale. When this occurs, ropes composed of the same material and performing the same function (such as forward breasting, after springs, etc.) are represented in the tests by a single line, without compromising the individual analysis of each real rope, since strength can be easily decomposed between them later.

The first tested plan was denominated "Plano Bordo" (Figure A 1 in Annex A), that was composed only by board ropes (launched from the vessel deck). In this arrangement, 24 steel ropes with $95 \mathrm{tf}$ MBL were used, and their distribution is indicated in Table 1.

The second mooring arrangement studied represented an addition of ropes in relation to the "Plano Bordo", complementing the mooring with the use of shore ropes. Shore ropes differ from the board ropes because they come from winches installed in the berth. In addition, in the case of this study, the board ropes are made of steel, while the shore ropes are made of HMPE (High Modulus Polyethylene), a material that enables a greater tensile strength, reaching a MBL of 180 tf. Hence, the second studied mooring arrangement added 17 shore ropes, totaling 41 ropes in the system. This mooring arrangement was called

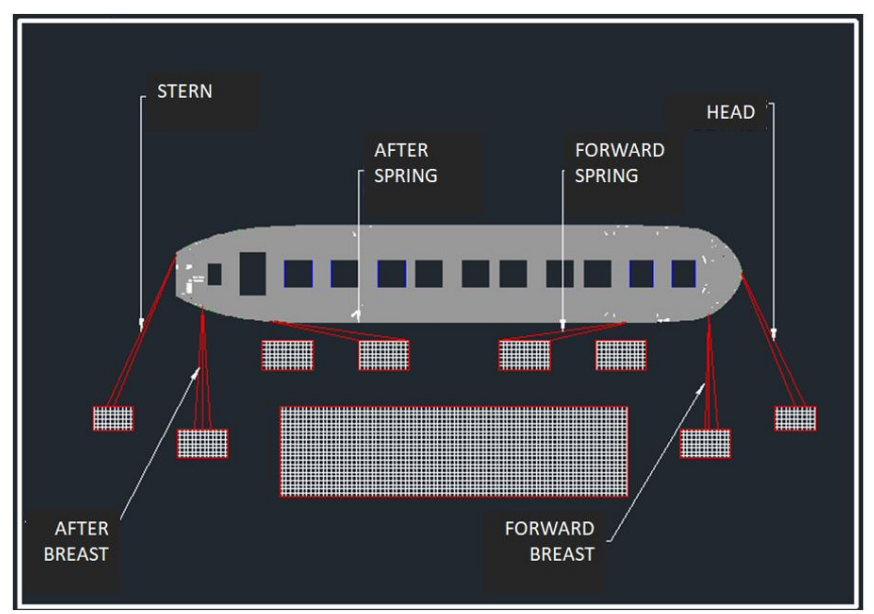

Figure 7. Simplified scheme representing the main types of ropes used in the mooring arrangement of vessels at port terminals.
"Plano Bordo + Terra" and is shown in Figure A 2 (Annex A). The shore winches were positioned at the points where the ropes suffered the major workloads, according to the distribution presented in Table 2.

Prior to all the tests, the ropes were tensioned to $10 \%$ of the MBL, as in actual mooring operations. Each test lasted for 90 minutes, representing a vessel being exposed to the most unfavorable tide moment during approximately 20 hours on real time scale. This test period was obtained through the analysis of several tests results in order to statistically define the minimum period to reliably represent all the kind of strengths experienced by the ropes on the different scenarios tested.

\section{RESULTS AND DISCUSSIONS}

The performed tests results were presented in tables containing the workload values, in percentage of the MBL, and the vessel displacements, in meters (m). The workloads results are the maximum values acquired in each set of ropes during the entire period of the simulation (90 minutes). In addition, to

Table 1. Composition of the mooring arrangement using only board ropes ("Plano Bordo").

\begin{tabular}{cccc}
\hline Group & Abbreviation & $\begin{array}{c}\mathbf{N}^{\mathbf{o}} \text { of } \\
\text { ropes }\end{array}$ & $\begin{array}{c}\text { Rope material } \\
(\mathbf{M B L})^{*}\end{array}$ \\
\hline Stern 1 & S1 & 2 & Steel $(95 \mathrm{tf})^{* *}$ \\
After Breast 1 & AB1 & 5 & Steel $(95 \mathrm{tf})$ \\
After Spring 1 & AS1 & 2 & Steel $(95 \mathrm{tf})$ \\
After Spring 3 & AS3 & 2 & Steel $(95$ tf) \\
Forward Spring 1 & FS1 & 2 & Steel $(95 \mathrm{tf})$ \\
Forward Spring 2 & FS2 & 2 & Steel $(95 \mathrm{tf})$ \\
Forward Breast 1 & FB1 & 5 & Steel $(95 \mathrm{tf})$ \\
Head 1 & H1 & 4 & Steel $(95 \mathrm{tf})$ \\
\hline *MBL: Minimum Breaking Load. **tf: ton force. &
\end{tabular}

Table 2. Composition of the plan using board and shore ropes ("Plano Bordo+Terra").

\begin{tabular}{ccccc}
\hline Group & Abbreviation & $\begin{array}{c}\mathbf{N}^{\mathbf{0}} \\
\text { of } \\
\text { ropes }\end{array}$ & Type & $\begin{array}{c}\text { Rope } \\
\text { Material } \\
\text { (MBL) }\end{array}$ \\
\hline Stern 1 & S1 & 2 & Shore & HMPE** $^{*}$ (180tf)*** \\
Stern 2 & S2 & 2 & Board & Steel (95tf) \\
After Breast 1 & AB1 & 5 & Board & Steel (95tf) \\
After Breast 2 & AB2 & 4 & Shore & HMPE (180tf) \\
After Spring 1 & AS1 & 2 & Board & Steel (95tf) \\
After Spring 2 & AS2 & 2 & Shore & HMPE (180tf) \\
After Spring 3 & AS3 & 2 & Board & Steel (95tf) \\
After Spring 4 & AS4 & 2 & Shore & HMPE (180tf) \\
Forward Spring 1 & FS1 & 2 & Board & Steel (95tf) \\
Forward Spring 2 & FS2 & 2 & Board & Steel (95tf) \\
Forward Spring 3 & FS3 & 2 & Shore & HMPE (180tf) \\
Forward Breast 1 & FB1 & 5 & Board & Steel (95tf) \\
Forward Breast 2 & FB2 & 3 & Shore & HMPE (180tf) \\
Head 1 & H1 & 4 & Board & Steel (95tf) \\
Head 2 & H2 & 2 & Shore & HMPE (180tf) \\
\hline
\end{tabular}

*MBL: Minimum Breaking Load. **HMPE: High Modulus Polyethylene. $* * * \mathrm{tf}$ : ton force. 
facilitate the assessment of the results, the values were presented in percentage terms with respect to the MBL of the rope. Thus, according to the criterion established by the OCIMF (2013) will be considered as the critical situation for a given rope when the workload value obtained exceeds the benchmark of $55 \%$. It is important to note that this does not mean that the rope will necessarily break, but it is a warning sign that the safety margin for this operation is below recommended.

Table 3 shows the results of the maximum strengths obtained in the ropes during the scale model simulations using the "Plano Bordo" (Figure A 1 in Annex A) for the fully loaded Valemax Vessel moored at the North Berth of Pier IV. The test was performed considering a tidal range of $5,5 \mathrm{~m}$ in flood and ebb conditions.

In Table 3 it is possible to observe, for flood condition with the tidal range of $5.5 \mathrm{~m}$, that the highest strength value were in the groups representing the heads and forward-breasting lines, reaching $43 \%$ and $48 \%$ of the MBL, respectively. These results can be explained by the high intensity and angle of the field of currents acting in the vessel, as illustrated in Figure 8. The tidal current field presented in Figure 8 was extracted from the Baía de São Marcos computational hydrodynamic model, developed and calibrated by CTH-USP, using Delft 3D ${ }^{\circledR}$ software, for the same tidal range $(5.5 \mathrm{~m})$ at MSL. The speed close to the berth is in the order of 1.5 to $2.0 \mathrm{~m} / \mathrm{s}$. The movement of the vessel during the test was acceptable considering the maximum allowed limits of $5.0 \mathrm{~m}$ for surge, $2.5 \mathrm{~m}$ for sway and $3^{\circ}$ for yaw, presenting no problem in the flood condition.

However, for the ebb condition in the same range (Table 3), the sea current speed tends to be higher, and the mooring arrangement did not present satisfactory results. The most requested ropes are the stern lines (S1) and the after-breasting lines (AB1), exceeding the adopted safety limit, with $59 \%$ e $89 \%$ of MBL, respectively. These high strengths values are caused by the tidal currents field that in the ebb cycle may reach speeds close to 6 knots, directly affecting the back of the vessel, which justifies the excessive displacement in sway. Figure 9 shows the tidal currents field in ebb condition, extracted from the computational model of Baáa de São Marcos, at the same tidal range $(5.5 \mathrm{~m})$ at the MSL moment.

Table 4 present the vessel movements measured during "Plano Bordo" tests for a tidal range of $5,5 \mathrm{~m}$, in the ebb and flood conditions.

Table 3. Workload results for the tests using "Plano Bordo". Tidal range of $5.5 \mathrm{~m}$ for ebb and flood conditions.

\begin{tabular}{|c|c|c|c|c|c|}
\hline \multicolumn{3}{|c|}{ 1/2 FLOOD TIDE $5.5 \mathrm{~m}$} & \multicolumn{3}{|c|}{ 1/2 EBB TIDE $5.5 \mathrm{~m}$} \\
\hline \multirow{2}{*}{$\begin{array}{c}\text { GROUP } \\
\text { S } 1\end{array}$} & \multicolumn{2}{|c|}{$\begin{array}{c}\text { STRENGTH } \\
\left(\mathrm{tf}^{*}\right)\end{array}$} & \multirow{2}{*}{$\begin{array}{c}\text { GROUP } \\
\text { S } 1\end{array}$} & \multicolumn{2}{|c|}{$\begin{array}{c}\text { STRENGTH } \\
(\mathrm{tf})^{*}\end{array}$} \\
\hline & $\mathrm{F}_{\text {Máx. }}$ & $13 \%$ & & $\mathrm{~F}_{\text {Máx. }}$ & $59 \%$ ** \\
\hline $\mathrm{AB} 1$ & $\mathrm{~F}_{\text {Máx. }}$ & $29 \%$ & $\mathrm{AB} 1$ & $\mathrm{~F}_{\text {Máx. }}$ & $89 \%$ ** \\
\hline AS1 & $\mathrm{F}_{\text {Máx. }}$ & $26 \%$ & AS1 & $\mathrm{F}_{\text {Máx. }}$ & $19 \%$ \\
\hline AS3 & $\mathrm{F}_{\text {Máx. }}$ & $24 \%$ & AS3 & $\mathrm{F}_{\text {Máx. }}$ & $17 \%$ \\
\hline FS1 & $\mathrm{F}_{\text {Máx. }}$ & $4 \%$ & FS1 & $\mathrm{F}_{\text {Máx. }}$ & $25 \%$ \\
\hline FS2 & $\mathrm{F}_{\text {Máx. }}$ & $8 \%$ & FS2 & $\mathrm{F}_{\text {Máx. }}$ & $34 \%$ \\
\hline FB1 & $\mathrm{F}_{\text {Máx. }}$ & $48 \%$ & FB1 & $\mathrm{F}_{\text {Máx. }}$ & $49 \%$ \\
\hline $\mathrm{H} 1$ & $\mathrm{~F}_{\text {Máx. }}$ & $43 \%$ & $\mathrm{H} 1$ & $\mathrm{~F}_{\text {Máx. }}$ & $41 \%$ \\
\hline
\end{tabular}

${ }^{*} \mathrm{tf}$ : ton force. ${ }^{* *}$ Higher than recommended values in red.

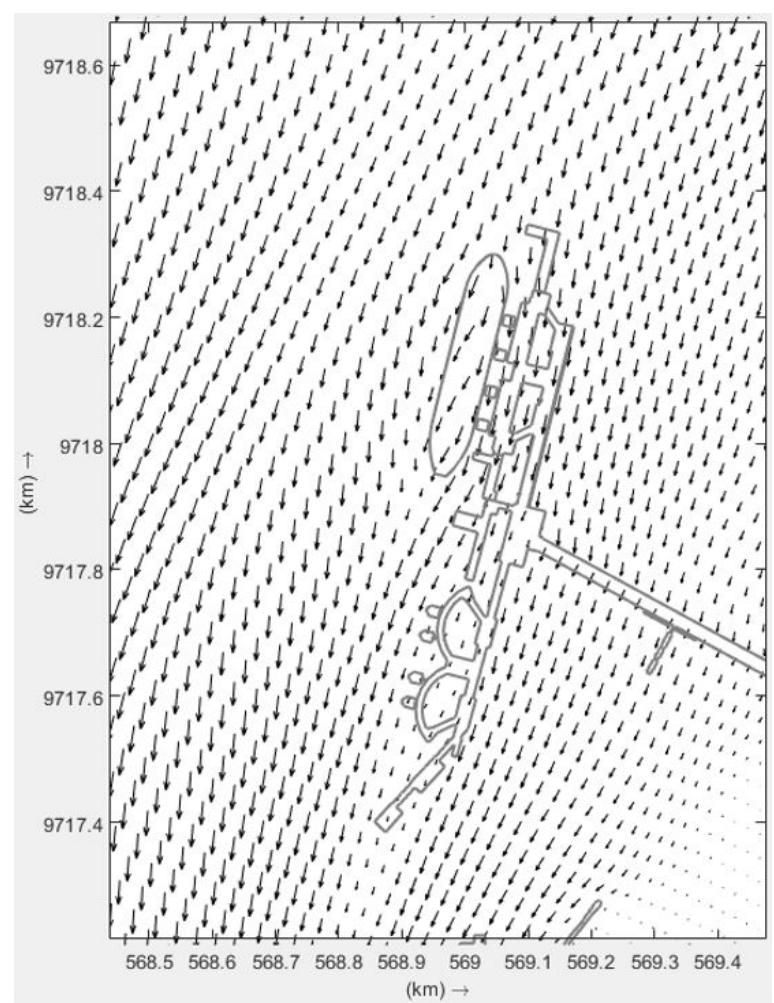

Figure 8. Velocity field near the North Berth of Pier IV to a flood of $5.5 \mathrm{~m}$ tidal range, at MSL. Result extracted from the hydrodynamic computational model of Baía de São Marcos developed by CTH-USP.

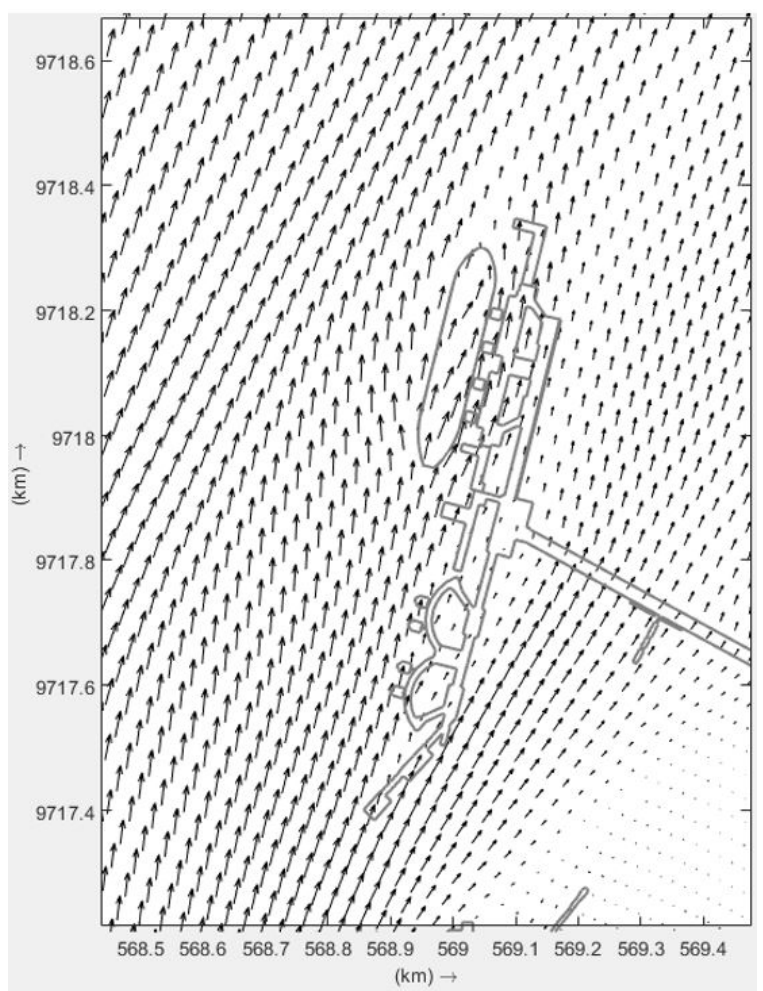

Figure 9. Velocity field near the North Berth of Pier IV to an ebb of $5.5 \mathrm{~m}$ tidal range, at MSL. Result extracted from the hydrodynamic computational model of Baía de São Marcos developed by CTH-USP. 
On Table 4 it is possible to observe that the movements results are consistent with the ropes workload assessment, indicating a displacement of the vessel from the mooring line of approximately $3 \mathrm{~m}$ of sway.

Therefore, with these results there was no need to carry out tests with higher tidal ranges, since for the tidal range of $5.5 \mathrm{~m}$ the arrangement did not meet the established safety criterion.

In this way, new tests were carried out to define a new mooring plan that would meet the recommended maximum strength and maximum displacement criteria. The proposed new mooring arrangement did not change the distribution and quantity of board ropes, but proposed to complement the system with shore ropes, which have a higher tensile strength (HMPE), using the "Plano Bordo+Terra". As can be seen in Figure A 2 (Annex A) mooring points with shore ropes were inserted in the groups of the heads and forward-breasting lines, where the strength values exceeded the recommended limits, is 55\% of MBL. In addition, to ensure greater safety, new mooring points were also inserted in the spring-line groups, both after and forward.

Table 5 shows the results of the maximum strengths obtained in the ropes during the physical model simulations using the "Plano Bordo+Terra" (Figure A 2 in Annex A) for the fully loaded Valemax Vessel docked in the North Berth of Pier

Table 4. Vessel Movements results measured during "Plano Bordo" tests for tidal range of $5.5 \mathrm{~m}$, in ebb and flood conditions.

\section{DISPLACEMENT FLOOD DISPLACEMENT EBB}

(m)

\begin{tabular}{lrlc}
\hline Sway After $(+)(\mathrm{m})$ & 1.14 & Sway After $(+)(\mathrm{m})$ & $3.65^{*}$ \\
Sway Fore $(+)(\mathrm{m})$ & 2.13 & Sway Fore $(+)(\mathrm{m})$ & $2.84^{*}$ \\
Yaw $\left(^{\circ}\right)$ & 0.32 & Yaw $\left(^{\circ}\right)$ & -0.87 \\
Surge - fore & 1.11 & Surge - fore & 1.21 \\
Surge - Aft & -0.77 & Surge - Aft & -0.18 \\
Surge (peak-peak) & 1.88 & Surge (peak-peak) & 1.39 \\
\hline
\end{tabular}

*Higher than recommended values in red.

Table 5. Workload results for the tests using "Plano Bordo + Terra". Tidal range of $5.5 \mathrm{~m}$ for ebb and flood conditions.

\begin{tabular}{|c|c|c|c|c|c|}
\hline \multicolumn{3}{|c|}{ 1/2 FLOOD TIDE $5.5 \mathrm{~m}$} & \multicolumn{3}{|c|}{ 1/2 EBB TIDE $5.5 \mathrm{~m}$} \\
\hline GROUP & STREN & $\mathrm{H}\left(\mathrm{tf}^{*}\right)$ & GROUP & STREN & $\mathrm{H}(\mathrm{tf})^{*}$ \\
\hline S1 & $\mathrm{F}_{\text {Máx. }}$ & $10 \%$ & S1 & $\mathrm{F}_{\text {Máx. }}$ & $26 \%$ \\
\hline S2 & $\mathrm{F}_{\text {Máx. }}$ & $9 \%$ & S2 & $\mathrm{F}_{\text {Máx. }}$ & $20 \%$ \\
\hline $\mathrm{AB} 1$ & $\mathrm{~F}_{\text {Máx. }}$ & $12 \%$ & $\mathrm{AB} 1$ & $\mathrm{~F}_{\text {Máx. }}$ & $11 \%$ \\
\hline AB2 & $\mathrm{F}_{\text {Máx. }}$ & $12 \%$ & AB2 & $\mathrm{F}_{\text {Máx. }}$ & $27 \%$ \\
\hline AS1 & $\mathrm{F}_{\text {Máx. }}$ & $11 \%$ & AS1 & $\mathrm{F}_{\text {Máx. }}$ & $5 \%$ \\
\hline AS2 & $\mathrm{F}_{\text {Máx. }}$ & $12 \%$ & AS2 & $\mathrm{F}_{\text {Máx. }}$ & $5 \%$ \\
\hline AS3 & $\mathrm{F}_{\text {Máx. }}$ & $11 \%$ & AS3 & $\mathrm{F}_{\text {Máx. }}$ & $7 \%$ \\
\hline AS4 & $\mathrm{F}_{\text {Máx. }}$ & $6 \%$ & AS4 & $\mathrm{F}_{\text {Máx. }}$ & $7 \%$ \\
\hline FS1 & $\mathrm{F}_{\text {Máx. }}$ & $11 \%$ & FS1 & $\mathrm{F}_{\text {Máx. }}$ & $13 \%$ \\
\hline FS2 & $\mathrm{F}_{\text {Máx. }}$ & $11 \%$ & FS2 & $\mathrm{F}_{\text {Máx. }}$ & $13 \%$ \\
\hline FS3 & $\mathrm{F}_{\text {Máx. }}$ & $14 \%$ & FS3 & $F_{\text {Máx. }}$ & $17 \%$ \\
\hline FB1 & $\mathrm{F}_{\text {Máx. }}$ & $19 \%$ & FB1 & $\mathrm{F}_{\text {Máx. }}$ & $14 \%$ \\
\hline FB2 & $F_{\text {Máx. }}$ & $28 \%$ & FB2 & $F_{\text {Máx. }}$ & $17 \%$ \\
\hline H1 & $\mathrm{F}_{\text {Máx. }}$ & $18 \%$ & H1 & $F_{\text {Máx. }}$ & $13 \%$ \\
\hline $\mathrm{H} 2$ & $F_{\text {Máx. }}$ & $23 \%$ & $\mathrm{H} 2$ & $\mathrm{~F}_{\text {Máx. }}$ & $12 \%$ \\
\hline
\end{tabular}

IV. The test was performed considering a tidal range of $5.5 \mathrm{~m}$ in flood and ebb conditions.

In Table 5, it is possible to observe, at the tidal range of $5.5 \mathrm{~m}$, that the extra shore ropes were capable to absorb the strength, and no rope presented values of workload above the stipulated limit.

Table 6 presents the vessel movements measured during "Plano Bordo + Terra" tests for a tidal range of $5.5 \mathrm{~m}$, in the ebb and flood conditions.

Table 6 is coherent with the strength results presented at Table 5, and it is possible to verify the reduction of vessel movement, providing greater stability.

The graphs in Figure 10 and Figure 11 show, for ebb condition (most critical), the comparison of the strength results in the board ropes between the "Bordo" and "Bordo+Terra" arrangements tests. It is possible to note a reduction in the strength results of around 50\%, moreover, the "Plano Bordo + Terra" presented a higher solidarity between all ropes in the mooring system.

The vessel movement was also reduced, keeping the vessel more stable, both in flood and ebb tide conditions. In this case, as the "Plano Bordo + Terra" presented satisfactory results, the tests were also carried out for the tidal ranges of $6.0 \mathrm{~m}$ and $6.5 \mathrm{~m}$, in which the velocities of currents are higher, in order to ensure the safety of the vessel in the berth for all environmental conditions that may occur in the region.

In Table 7 are presented the results of the maximum strengths obtained in the ropes during the scale model simulations

Table 6. Vessel Movements results measured during "Plano Bordo + Terra" tests for tidal range of $5.5 \mathrm{~m}$, in ebb and flood conditions.

\begin{tabular}{lllc}
\hline $\begin{array}{l}\text { DISPLACEMENT FLOOD } \\
(\mathbf{m})\end{array}$ & \multicolumn{1}{c}{$\begin{array}{c}\text { DISPLACEMENT EBB } \\
(\mathbf{m})\end{array}$} \\
\hline Sway After (m) & 0.15 & Sway After (m) & -0.41 \\
Sway Fore (m) & 0.44 & Sway Fore (m) & 0.18 \\
Yaw $\left(^{\circ}\right)$ & 0.23 & Yaw $\left(^{\circ}\right)$ & 0.61 \\
Surge - fore & 0.08 & Surge - fore & 0.9 \\
Surge - After & 0.03 & Surge - After & 0.75 \\
Surge (peak-peak) & 0.11 & $\begin{array}{l}\text { Surge (peak- } \\
\text { peak) }\end{array}$ & 1.65 \\
& &
\end{tabular}

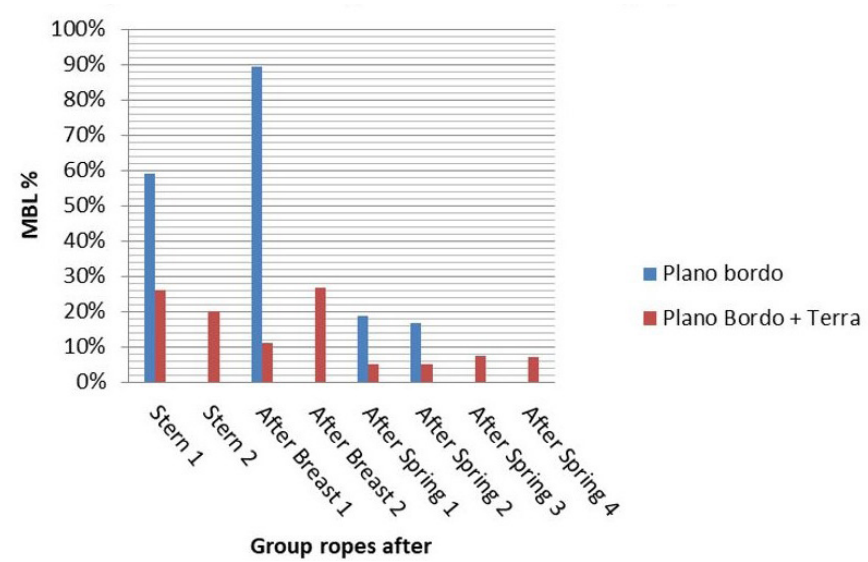

Figure 10. Comparison between the tested plans, with focus on after ropes (tidal range $5.5 \mathrm{~m}$ ). 


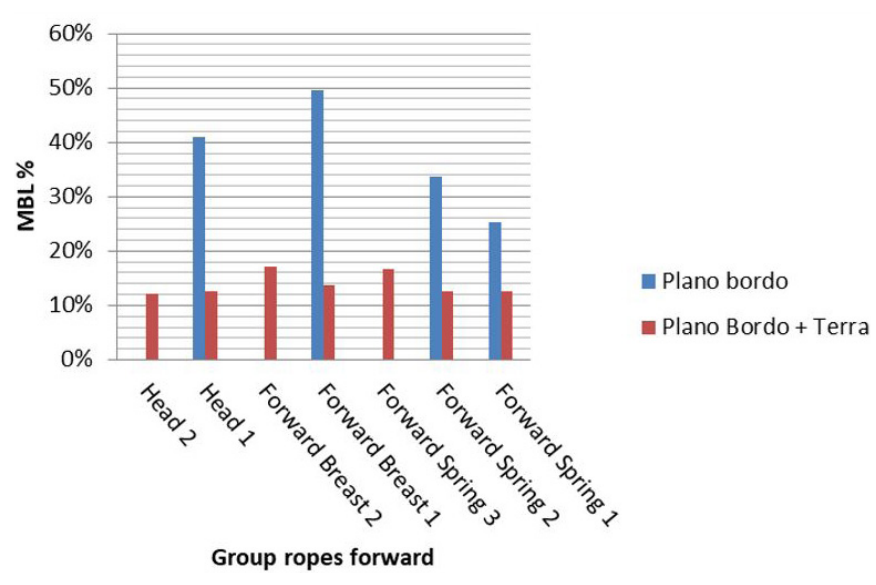

Figure 11. Comparison between the tested plans, with focus on forward ropes (Range $5.5 \mathrm{~m}$ ).

Table 7. Workload results for the tests using "Plano Bordo + Terra". Tidal range of $6.0 \mathrm{~m}$ for ebb and flood conditions.

\begin{tabular}{|c|c|c|c|c|c|}
\hline \multicolumn{3}{|c|}{ 1/2 FLOOD TIDE $6.0 \mathrm{~m}$} & \multicolumn{3}{|c|}{ 1/2 EBB TIDE $6.0 \mathrm{~m}$} \\
\hline \multirow{2}{*}{$\frac{\text { GROUP }}{\mathrm{S} 1}$} & \multicolumn{2}{|c|}{$\begin{array}{c}\text { STRENGTH } \\
\left(\mathrm{tf}^{*}\right)\end{array}$} & \multirow{2}{*}{$\begin{array}{c}\text { GROUP } \\
\text { S1 }\end{array}$} & \multicolumn{2}{|c|}{$\begin{array}{c}\text { STRENGTH } \\
\text { (tf) }{ }^{*}\end{array}$} \\
\hline & $\mathrm{F}_{\text {Máx. }}$ & $8 \%$ & & $\mathrm{~F}_{\text {Máx. }}$ & $18 \%$ \\
\hline S2 & $\mathrm{F}_{\text {Max. }}$ & $9 \%$ & S2 & $\mathrm{F}_{\text {Máx. }}$ & $20 \%$ \\
\hline $\mathrm{AB} 1$ & $\mathrm{~F}_{\text {Máx. }}$ & $6 \%$ & AB1 & $\mathrm{F}_{\text {Máx. }}$ & $12 \%$ \\
\hline $\mathrm{AB} 2$ & $\mathrm{~F}_{\text {Máx. }}$ & $12 \%$ & $\mathrm{AB} 2$ & $\mathrm{~F}_{\text {Max. }}$ & $29 \%$ \\
\hline AS1 & $\mathrm{F}_{\text {Max. }}$ & $9 \%$ & AS1 & $\mathrm{F}_{\text {Máx. }}$ & $5 \%$ \\
\hline AS2 & $\mathrm{F}_{\text {Máx. }}$ & $15 \%$ & AS2 & $\mathrm{F}_{\text {Máx. }}$ & $7 \%$ \\
\hline AS3 & $\mathrm{F}_{\text {Máx. }}$ & $12 \%$ & AS3 & $\mathrm{F}_{\text {Máx. }}$ & $9 \%$ \\
\hline AS4 & $\mathrm{F}_{\text {Máx. }}$ & $8 \%$ & AS4 & $\mathrm{F}_{\text {Máx. }}$ & $6 \%$ \\
\hline FS1 & $\mathrm{F}_{\text {Máx. }}$ & $9 \%$ & FS1 & $\mathrm{F}_{\text {Máx. }}$ & $14 \%$ \\
\hline FS2 & $\mathrm{F}_{\text {Máx. }}$ & $11 \%$ & FS2 & $\mathrm{F}_{\text {Máx. }}$ & $7 \%$ \\
\hline FS3 & $\mathrm{F}_{\text {Máx. }}$ & $14 \%$ & FS3 & $\mathrm{F}_{\text {Máx. }}$ & $21 \%$ \\
\hline FB1 & $\mathrm{F}_{\text {Máx. }}$ & $23 \%$ & FB1 & $\mathrm{F}_{\text {Máx. }}$ & $16 \%$ \\
\hline FB2 & $\mathrm{F}_{\text {Máx. }}$ & $37 \%$ & FB2 & $\mathrm{F}_{\text {Máx. }}$ & $21 \%$ \\
\hline H1 & $\mathrm{F}_{\text {Máx. }}$ & $22 \%$ & H1 & $\mathrm{F}_{\text {Máx. }}$ & $14 \%$ \\
\hline $\mathrm{H} 2$ & $F_{\text {Max. }}$ & $28 \%$ & $\mathrm{H} 2$ & $\mathrm{~F}_{\text {Máx. }}$ & $13 \%$ \\
\hline
\end{tabular}

* tf: ton force

using the "Plano Bordo+Terra" (Figure A 2 attached) for the fully loaded Valemax Vessel in the North Berth of Pier IV. The test was performed considering a tidal range of $6.0 \mathrm{~m}$ in flood and ebb conditions.

In Table 7, it is noted that for the range of $6.0 \mathrm{~m}$, the mooring arrangement "Plano Bordo+Terra" continues to resist the efforts coming from the tidal current, not presenting rope groups with values above the safety limit.

Table 8 presents the vessel movements measured during "Plano Bordo + Terra" tests for a tidal range of $6.0 \mathrm{~m}$, in the ebb and flood conditions.

In Table 8, it is possible to observe that no measured displacement during the test exceeds the established limits.

Table 9 and Table 10 present the results of the maximum strength obtained in the ropes and vessel movements during the scale model simulations using the "Plano Bordo+Terra" (Figure A 2 in annex) for the fully loaded Valemax Vessel in the North Berth
Table 8. Vessel Movements results measured during "Plano Bordo + Terra" tests for tidal range of $6.0 \mathrm{~m}$, in ebb and flood conditions.

\begin{tabular}{lclc}
\hline $\begin{array}{l}\text { DISPLACEMENT FLOOD } \\
(\mathbf{m})\end{array}$ & $\begin{array}{c}\text { DISPLACEMENT EBB } \\
(\mathbf{m})\end{array}$ \\
\hline Sway After $(+)(\mathrm{m})$ & 0.31 & Sway After $(+)(\mathrm{m})$ & 0.02 \\
Sway Fore $(+)(\mathrm{m})$ & 0.67 & Sway Fore $(+)(\mathrm{m})$ & 0.36 \\
Yaw $\left(^{\circ}\right)$ & 0.27 & Yaw $\left(^{\circ}\right)$ & 0.57 \\
Surge - fore & 0.24 & Surge - fore & 0.36 \\
Surge - After & 0.17 & Surge - After & 0.17 \\
Surge (peak-peak) & 0.41 & Surge (peak-peak) & 0.53 \\
\hline
\end{tabular}

Table 9. Workload results for the tests using "Plano Bordo + Terra". Tidal range of $6.5 \mathrm{~m}$ for ebb and flood conditions.

\begin{tabular}{|c|c|c|c|c|c|}
\hline \multicolumn{3}{|c|}{ 1/2 FLOOD TIDE $6.5 \mathrm{~m}$} & \multicolumn{3}{|c|}{ 1/2 EBB TIDE $6.5 \mathrm{~m}$} \\
\hline GROUP & STREI & $\mathrm{H}(\mathrm{tf})^{*}$ & GROUP & STREI & $\mathrm{H}(\mathrm{tf})^{*}$ \\
\hline S1 & $\mathrm{F}_{\text {Máx. }}$ & $9 \%$ & S1 & $\mathrm{F}_{\text {Máx. }}$ & $32 \%$ \\
\hline S2 & $\mathrm{F}_{\text {Máx. }}$ & $9 \%$ & S2 & $\mathrm{F}_{\text {Máx. }}$ & $23 \%$ \\
\hline AB1 & $\mathrm{F}_{\text {Máx. }}$ & $7 \%$ & AB1 & $\mathrm{F}_{\text {Máx. }}$ & $14 \%$ \\
\hline $\mathrm{AB} 2$ & $\mathrm{~F}_{\text {Máx. }}$ & $14 \%$ & AB2 & $\mathrm{F}_{\text {Máx. }}$ & $36 \%$ \\
\hline AS1 & $\mathrm{F}_{\text {Máx. }}$ & $9 \%$ & AS1 & $\mathrm{F}_{\text {Máx. }}$ & $8 \%$ \\
\hline AS2 & $\mathrm{F}_{\text {Máx. }}$ & $17 \%$ & AS2 & $F_{\text {Máx. }}$ & $8 \%$ \\
\hline AS3 & $\mathrm{F}_{\text {Máx. }}$ & $12 \%$ & AS3 & $\mathrm{F}_{\text {Máx. }}$ & $9 \%$ \\
\hline AS4 & $\mathrm{F}_{\text {Máx. }}$ & $8 \%$ & AS4 & $\mathrm{F}_{\text {Máx. }}$ & $6 \%$ \\
\hline FS1 & $\mathrm{F}_{\text {Máx. }}$ & $8 \%$ & FS1 & $\mathrm{F}_{\text {Máx. }}$ & $17 \%$ \\
\hline FS2 & $\mathrm{F}_{\text {Máx. }}$ & $12 \%$ & FS2 & $\mathrm{F}_{\text {Máx. }}$ & $15 \%$ \\
\hline FS3 & $\mathrm{F}_{\text {Máx. }}$ & $14 \%$ & FS3 & $F_{\text {Máx. }}$ & $25 \%$ \\
\hline FB1 & $\mathrm{F}_{\text {Máx. }}$ & $24 \%$ & FB1 & $\mathrm{F}_{\text {Máx. }}$ & $19 \%$ \\
\hline FB2 & $\mathrm{F}_{\text {Máx. }}$ & $38 \%$ & FB2 & $\mathrm{F}_{\text {Máx. }}$ & $26 \%$ \\
\hline H1 & $\mathrm{F}_{\text {Máx. }}$ & $23 \%$ & H1 & $F_{\text {Máx. }}$ & $17 \%$ \\
\hline $\mathrm{H} 2$ & $\mathrm{~F}_{\text {Máx. }}$ & $30 \%$ & $\mathrm{H} 2$ & $\mathrm{~F}_{\text {Máx. }}$ & $17 \%$ \\
\hline
\end{tabular}

Table 10. Vessel Movements results measured during "Plano Bordo + Terra" tests for tidal range of $6.5 \mathrm{~m}$, in ebb and flood conditions.

\begin{tabular}{lclc}
\hline $\begin{array}{c}\text { DISPLACEMENT FLOOD } \\
(\mathbf{m})\end{array}$ & \multicolumn{1}{c}{$\begin{array}{c}\text { DISPLACEMENT EBB } \\
(\mathbf{m})\end{array}$} \\
\hline Sway After $(+)(\mathrm{m})$ & 0.32 & Sway After $(+)(\mathrm{m})$ & 0.02 \\
Sway Fore $(+)(\mathrm{m})$ & 0.67 & Sway Fore $(+)(\mathrm{m})$ & 0.66 \\
Yaw $\left(^{\circ}\right)$ & 0.24 & Yaw $\left(^{\circ}\right)$ & 0.91 \\
Surge - fore & 0.25 & Surge - fore & 0.41 \\
Surge - After & 0.18 & Surge - After & 0.6 \\
Surge (peak-peak) & 0.43 & Surge (peak-peak) & 0.57 \\
\hline
\end{tabular}

of Pier IV. The test was performed considering a tidal range of $6.5 \mathrm{~m}$ in flood and ebb conditions.

The results presented in Table 9 and Table 10 showed that "Plano Bordo+Terra" met all established safety criteria, even considering the most rigorous tide condition established for operations in this berth, which refers to the tidal range of $6.5 \mathrm{~m}$

\section{CONCLUSIONS}

The application of small-scale hydraulic physical modeling in the study of mooring vessels in port terminals is highly recommended when the port terminal is installed in locations where action of the 
currents and waves fields on the vessel is complex and difficult to represent or evaluate by other techniques. When properly calibrated with field data, the scale models reproduce the flow conditions and their interaction with the vessel much more accurately than any other tool, since they represent the phenomenon completely, provided that it is properly demonstrated that the effects of scale assessment of the phenomenon are secondary. Especially in the case of Engineering projects that involve the operation with large vessels, the application of the physical modeling is fully justified, despite the generally higher costs and deadlines associated with this type of model.

The use of the TPPM scale model to evaluate the Valemax (400,000 DWT) mooring plans in the North Berth of Pier IV was a fundamental tool to guarantee the safety of the terminal during the cargo handling operation, even considering the most severe environmental conditions in the region.

The results of the tests on the scale model identified that it was not possible to ensure safe mooring of the vessel for tides with ranges of $5.5 \mathrm{~m}$ or more only with the use of vessel borne ropes, which would represent an operational constraint during 30\% of the time for the Valemax vessels in the North Berth of Pier IV.

Thus, to increase the availability of the berth, new tests were carried out complementing the board mooring lines with the use of shore ropes operated by the terminal. These tests allowed the definition of a mooring arrangement for safe operation in all tidal ranges tested up to $6.5 \mathrm{~m}$.

The results of the scale model were used directly in the design of this berth, helping in the definition of the quantity and positioning of the shore winches. In addition, the results obtained made the operation of this berth viable for $100 \%$ of the time, which means a gain of $30 \%$ compared to the original condition considering only the use of board ropes. This improvement in operating efficiency of the berth represents an increase in cargo handling capacity of approximately 34 million tons per year.

\section{REFERENCES}

ALFREDINI, P. A técnica de traçadores em modelos de fundo fixo aplicada a estudos sedimentológicos. 1988. Tese (Doutorado em Engenharia) Escola Politécnica da Universidade de São Paulo, São Paulo, 1988.

ASCE - AMERICAN SOCIETY OF CIVIL ENGINEERS. Manual and reports on engineering practice no. 129: mooring of vessels to piers and wharves. Virginia: ASCE, 2014.
BERNARDINO, J. C. M. Abordagem experimental para avaliação de manobras de navios em modelos físicos de espaços náuticos. 2015. Tese (Doutorado) - Departamento de Engenharia de Hidráulica e Ambiental, Escola Politécnica da Universidade de São Paulo, São Paulo, 2015.

FCTH - FUNDAÇÃO CENTRO TECNOLÓGICO DE HIDRAÚLICA. Descrição da concepşão e operação do modelo físico do Terminal Ponta da Madeira: RL-3000KP-X-09820. São Paulo: Laboratório de Hidráulica, Escola Politécnica, Universidade de São Paulo, 2015.

HUGHES, S. A. Physical models and laboratory techniques in Coastal Engineering. New Jersey: World Scientific Publishing, 2005. 588 p. (Advanced Series on Ocean Engineering, vol. 7). https://doi. org/10.1142/2154.

KOBUS, H. Hydraulics modeling. Bonn: International Association for Hydro-Environment Engineering and Research, 1981.

NOVAK, P.; CABELKA, J. Models in hydraulic engineering: physical principles and design applications. Boston: Pitman, 1981.

OCIMF - Oil Companies International Marine Forum. Mooring equipment guidelines. 3rd ed. London: OCIMF, 2013.

PIANC - Permanent International Association of Navigation Congresses. Criteria for movements of moored ships in harbours. Brussels: PIANC, 1995. Report Working Group no. 24. (Bulletin, 88).

\section{Authors contributions}

Rafael Esferra: Paper planning, definition and implementation of the methodology, bibliographical research, analysis and conclusions from the results, writing and preparation of figures and tables.

José Carlos de Melo Bernardino: Paper planning, definition and implementation of the methodology, bibliographical research, analysis and conclusions from the results, writing and preparation of figures and tables.

Paolo Alfredini: Supervisor of the study; structuring and revision of the paper; discussion of the results. 
Annex A. Mooring arrangement.

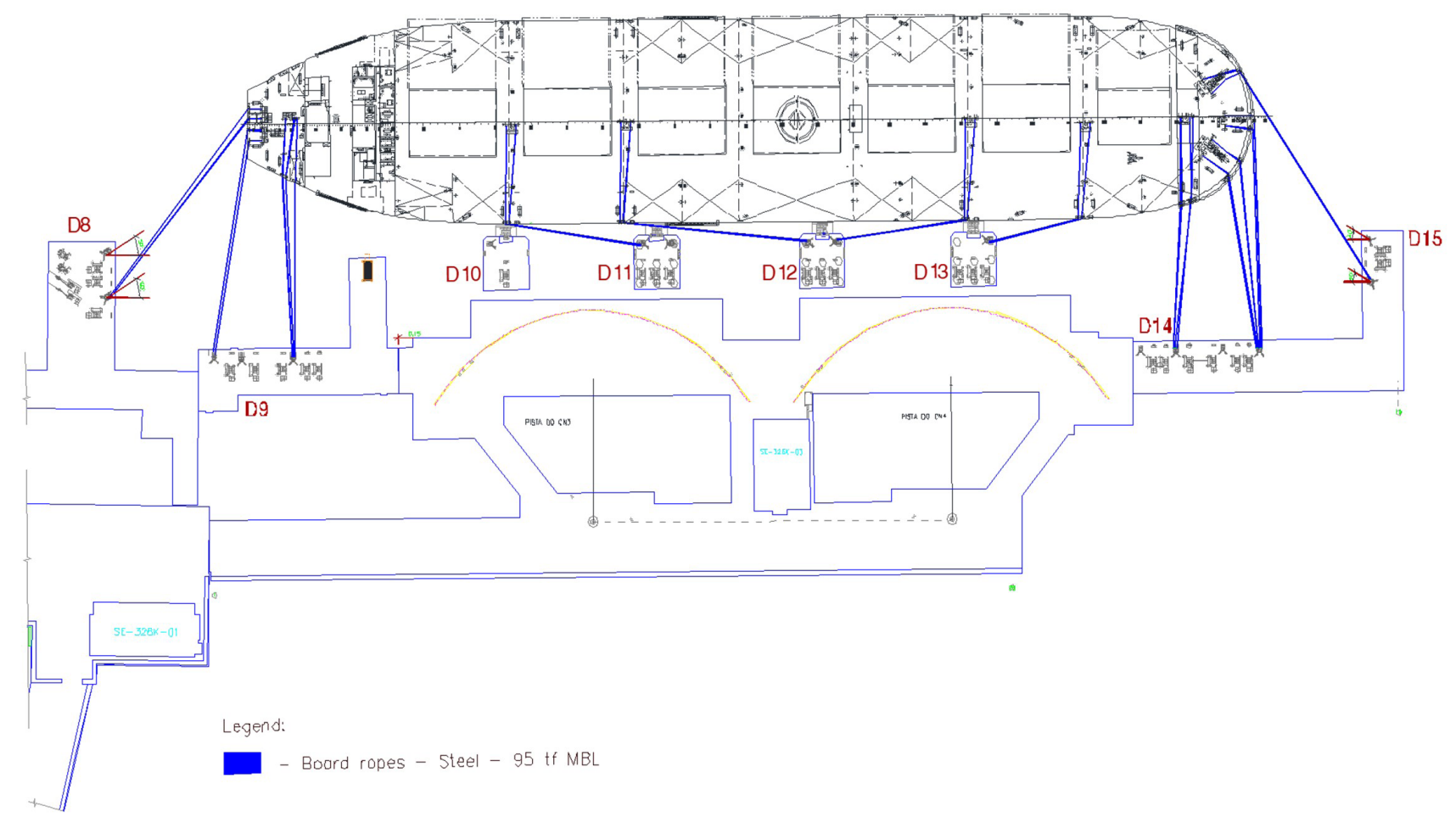

Figure A 1. Mooring Arrangement "Plano Bordo".

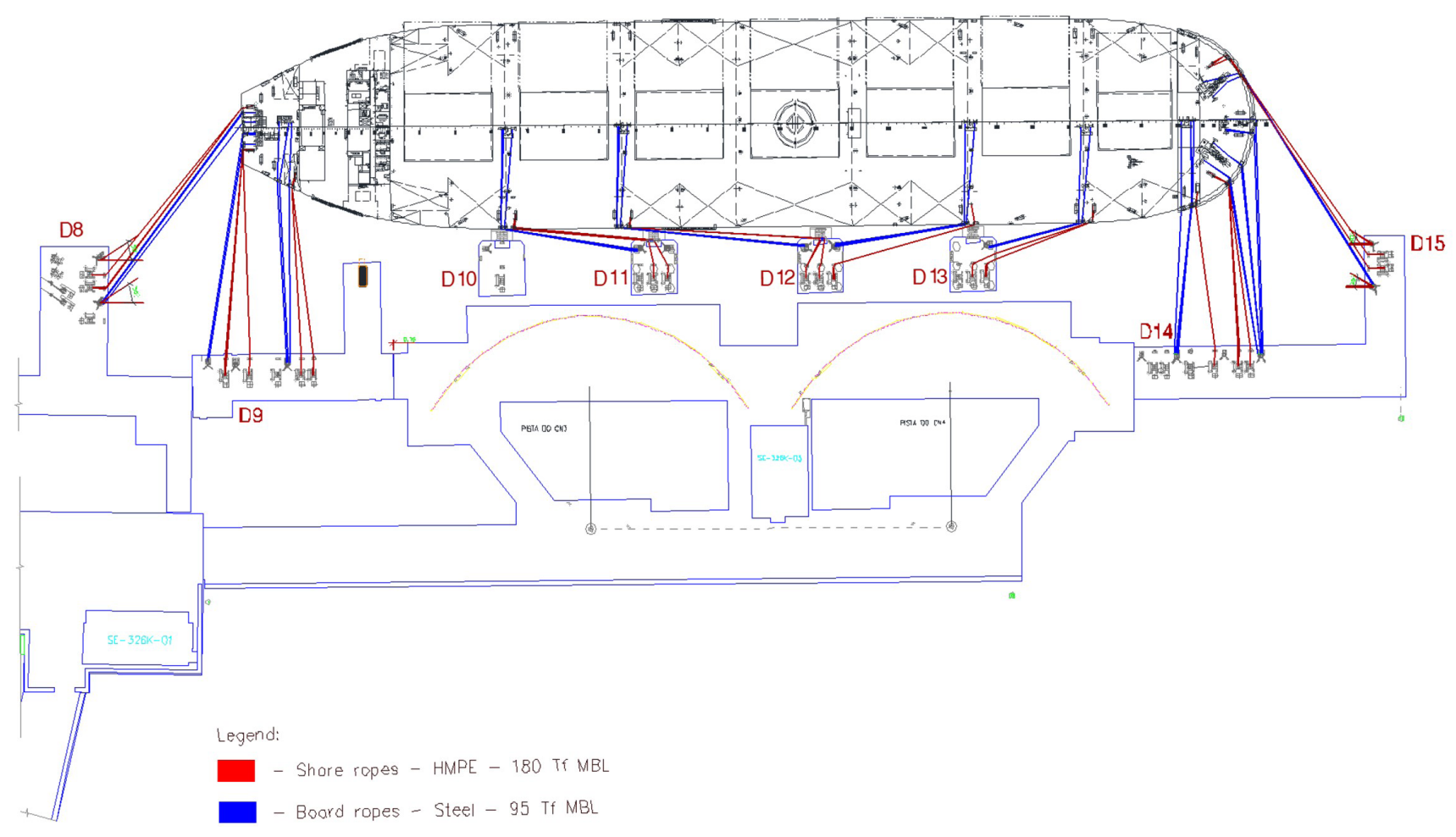

Figure A 2. Mooring Arrangement "Plano Bordo+Terra". 